\title{
Efficiency enhancement of natural dye sensitized solar cell by optimizing electrode fabrication parameters
}

\author{
M. Khalid Hossain ${ }^{1}$, M.F. Pervez ${ }^{1}$, S. Tayyaba ${ }^{2}$, M. Jalal Uddin ${ }^{3}$, A.A. Mortuza ${ }^{1}$, \\ M.N.H. MIA ${ }^{1}$, M.S. MANIR ${ }^{1}$, M.R. KARIM ${ }^{4}$, MUBARAK A. KHAN ${ }^{1, *}$ \\ ${ }^{1}$ Atomic Energy Research Establishment, Bangladesh Atomic Energy Commission, \\ GPO Box. 3787, Dhaka 1349, Bangladesh \\ ${ }^{2}$ Department of Computer Engineering, The University of Lahore, Lahore 54000, Pakistan \\ ${ }^{3}$ Department of Applied Physics, Electronics \& Communication Engineering, Islamic University, Kushtia 7003, Bangladesh \\ ${ }^{4}$ Department of Chemical Engineering, Z.H. Sikder University of Science \& Technology, Shariatpur, Bangladesh
}

\begin{abstract}
Efficiency of dye-sensitized solar cell (DSSC) depends on several interrelated factors such as type and concentration of dye, type and thickness of photoelectrode and counter electrode. Optimized combination of these factors leads to a more efficient cell. This paper presents the effect of these parameters on cell efficiency. $\mathrm{TiO}_{2}$ nanoporous thin films of different thicknesses $(5 \mu \mathrm{m}$ to $25 \mu \mathrm{m}$ ) were fabricated on indium doped tin oxide (ITO) coated glass by doctor blading method and characterized by inverted microscope, stylus surface profiler and scanning electron microscope (SEM). Natural organic dye of different concentrations, extracted from turmeric, was prepared with ethanol solvent. Different combinations of dye concentrations and film thicknesses along with different types of carbon catalyst have been investigated by I-V characterization. The result shows that the cell made of a counter electrode catalyst material prepared by candle flame carbon combined with about $15 \mu \mathrm{m}$ thick photoelectrode and $100 \mathrm{mg} / \mathrm{mL}$ dye in ethanol solvent, achieves the highest efficiency of $0.45 \%$, with open circuit voltage of $566 \mathrm{mV}$ and short circuit current density of $1.02 \mathrm{~mA} / \mathrm{cm}^{2}$.
\end{abstract}

Keywords: nanostructured $\mathrm{TiO}_{2}$; DSSC electrode; SEM analysis; surface morphology; cell efficiency

\section{Introduction}

Nowadays, it is becoming ever more important to search alternative inexpensive and efficient energy sources that can produce clean, inexhaustible energy playing a vital role for the development of a globally sustainable society [1-3]. Until now, solar energy harvesting using a photovoltaic cell is the most easily exploitable, sustainable, quiet, environment-friendly and adjustable to various applications among the renewable power sources [4-7].

Various types of photovoltaic cells have been developed so far. Though in 1991 Grätzel along with his co-workers developed a new type of solar cell known as dye-sensitized solar cell (DSSC) [5], it has gained significant attention in recent years. It is characterized by low-cost manufacturing process, ease of fabrication, good performance under diffuse light conditions, and modifiable aesthetic

*E-mail: makhan.inst@gmail.com features such as color, transparency, and flexibility [8-12]. Basically, DSSC is comprised of a transparent conducting glass electrode with a porous layer of semiconductor (e.g. $\mathrm{TiO}_{2}$ ) coated with a dye (which can be organic, inorganic or hybrid), an electrolyte layer containing the iodine/triiodine $\left(\mathrm{I}^{-} / \mathrm{I}_{3}^{-}\right)$redox couple, and a counter electrode typically coated with graphite or platinum [13-17]. Dye sensitized solar cells (DSSCs) function by sensitizing nano-particulate photoanode (DSSC's anode, i.e. working electrode) or photocathode semiconductor films. Dyes are referred to as "sensitizer" that sensitizes wide band gap semiconductors. In DSSCs, charge separation by kinetic competition is similar to natural photosynthesis where the dye substitutes chlorophylls, nano-structured semiconductor layer substitutes, nicotinamide adenine dinucleotide phosphate and carbon dioxide act as the electron acceptor [3-8].

The performance of a DSSC largely depends on the dye sensitizer and the photoanode 
acceptor materials [3]. Titanium dioxide semiconductor nanoporous thin film acting as a photoanode provides a high surface area that adsorbs dye molecules facilitating efficient injection of electrons into its conduction band [8, 18]. Moreover, cell efficiency is related to the range of light absorption spectrum which, in turn, is related to energy gap between the highest occupied molecular orbital (HOMO) and the lowest unoccupied molecular orbital (LUMO) of the sensitizer. A small energy gap that is similar to photon energy coming from the sun is required to absorb a big portion of the solar spectrum. Additionally, the energy levels of HOMO and LUMO need to match with the redox potential of the redox couple that is present in the electrolyte solution [18]. In our laboratories, we have recently used the dye obtained from turmeric (Curcuma Longa sp.) - a natural dye - to observe the effect of photovoltaic performance. Analysis was performed for the natural dye extracting solvents and the impact of sensitization time on photovoltaic performance of DSSCs [19]. However, the effect of DSSCs electrode fabrication parameters in case of turmeric sensitizer has not been studied yet.

The objective of this research work is to fabricate more efficient DSSC based on natural dye sensitizer by optimizing several cell fabrication parameters, namely thickness of titanium dioxide photoanode layer, concentration of natural dye solution and counter electrode materials. The effect of natural dye of different concentrations with varying soaking time (dye absorption/dipping time) on different thickness titanium dioxide layers and different counter electrodes made of different catalyst materials has been studied. Moreover, surface morphology of titanium dioxide layers of the most efficient cell found among the cells of this experiment has been taken into account to understand the role of surface properties on cell efficiency.

\section{Materials and methods}

\subsection{Materials}

Several materials including indium tin oxide (ITO) coated glass slides (Dyesol, Australia), titanium dioxide $\mathrm{TiO}_{2}$ nanopowder
(Degussa P25, USA), titanium IV isopropoxide (TTIP) Ti[OCH( $\left.\left(\mathrm{CH}_{3}\right)_{2}\right]_{4}$ (Merck, Germany), $\mathrm{HO}\left(\mathrm{C}_{2} \mathrm{H}_{4} \mathrm{O}\right)_{n} \mathrm{H}$ - polyethylene glycol 6000 (PEG), Triton X-100 - $\mathrm{C}_{8} \mathrm{H}_{17} \mathrm{C}_{6} \mathrm{H}_{4}\left(\mathrm{OCH}_{2} \mathrm{CH}_{2}\right) \mathrm{nOH}$ (Merck, Germany), citric acid $\left(\mathrm{C}_{6} \mathrm{H}_{8} \mathrm{O}_{7}\right)$, dye extracted from turmeric (Curcuma Longa sp., local Bangladeshi name holud), carbon (from tip of candle flame), potassium iodide (KI), iodine $\left(\mathrm{I}_{2}\right)$, etc. were used to fabricate a complete DSSC.

\subsection{Methods}

\subsubsection{Extraction of natural dye sensitizers}

After washing in a beaker with distilled water, the oven was used to dry the beaker at temperature of $60^{\circ} \mathrm{C}$ and then it was cooled naturally up to $25^{\circ} \mathrm{C}$. Next, the turmeric in dry form with weight of $5 \mathrm{~g}$ was dipped at different volumes $(50 \mathrm{~mL}$, $100 \mathrm{~mL}, 200 \mathrm{~mL}$ ) of ethanol solvents in three dried separate beakers to prepare the dye solutions of different concentrations. The beakers, after sealing the upper part with aluminum foil, were kept in dark room to extract color by self-extraction process.

\subsubsection{Preparation of $\mathrm{TiO}_{2}$ photoanode}

$1.0 \mathrm{~g} \mathrm{TiO}_{2}$ nanopowder (Degussa P25), $0.2 \mathrm{~mL}$ titanium (IV) isopropoxide, $1.0 \mathrm{~mL}$ citric acid $(0.1 \mathrm{M}), 0.1 \mathrm{~mL}$ polyethylene glycol and $0.05 \mathrm{~mL}$ nonionic surfactant Triton X-100 were mixed, stirred for a few minutes and sonicated using an ultrasonic bath (Model: SB-3200 BTBM, China) for 20 minutes to make a homogeneous paste. This precursor paste was used to coat ITO glass substrates (surface area $=1 \mathrm{~cm}^{2}$ and surface resistance $15 \mathrm{ohm} / \mathrm{cm}^{2}$ ) using doctor blade method, and then the substrates were annealed at $450{ }^{\circ} \mathrm{C}$ for 1 hour [20]. After heat treatment, the glass substrates were cooled down slowly for 12 hours to room temperature. At next stage, the substrates were immersed into the each natural dye beaker for different time durations namely 30 minutes, 1 hour, 2 hours and 3 hours in a dark room to adsorb the dye molecules with varying amount onto the nanoporous $\mathrm{TiO}_{2}$ surface. Eventually, the dye was adsorbed by the substrates and after that, water and ethanol were used to wash the substrates for many times. Then, the substrates were dried 
for few minutes naturally in air to get the finished photoanodes.

\subsubsection{Preparation of liquid electrolyte}

$0.127 \mathrm{~g}(0.05 \mathrm{M})$ iodine and $0.83 \mathrm{~g}(0.5 \mathrm{M})$ potassium iodide were mixed thoroughly in $10 \mathrm{~mL}$ ethylene glycol $\left(\mathrm{C}_{2} \mathrm{H}_{6} \mathrm{O}_{2}\right)$. This solution, which was used as DSSC electrolyte, was stored in a black bottle sealed with aluminum foil paper [21].

\subsubsection{Preparation of counter electrode}

To prepare counter electrodes, we collected carbon from various sources, such as carbon from recycled battery, HB pencil, 6HB pencil, wood coal, bamboo coal, and a tip of candle flame. Then, six types of counter electrodes have been prepared by using these different forms of carbon according to our previous study [20]. Here, the conductive side of one ITO coated glass was placed over the tip of a candle flame for $30 \mathrm{~s}$ to get a dark shade of carbon for one of the counter electrodes [19].

\subsubsection{Fabrication DSSC device}

Photoelectrode with dye adsorbed into the $\mathrm{TiO}_{2}$ paste coated surface and the carbon coated surface of counter electrode were set face to face using two binder clips. Afterward, two drops of the electrolyte solution were poured between the two electrodes and sealed with insulation tape properly to prevent leak out the electrolyte. Finally, the two electrodes were connected with connecting wire making the fabricated cell capable of harvesting energy from light.

\section{Characterization of DSSC cells}

\subsection{Electrical characterization and mea- surements}

The experimental setup for measuring the photoelectric parameters such as open-circuit voltage $\left(\mathrm{V}_{\mathrm{oc}}\right)$, short-circuit current density $\left(\mathrm{J}_{\mathrm{sc}}\right)$, and power density $\left(\mathrm{mW} / \mathrm{cm}^{2}\right)$ has been described in $\mathrm{Fa}-$ tai et al. [22]. One variable resistor (1000 ohm), two high precision multimeters, one fabricated cell and some connecting wires were required for the complete setup. The whole setup was placed in a handmade sun simulator of approximately
$100 \mathrm{~mW} / \mathrm{cm}^{2}$ illumination power. To obtain different current values corresponding to different voltage values, the value of variable resistor was varied. Fill factor (FF) of the DSSC was obtained by:

$$
F F=\left(J_{\max } \times V_{\text {max }}\right) /\left(J_{s c} \times V_{o c}\right)
$$

where $\mathrm{J}_{\mathrm{sc}}$ and $\mathrm{V}_{\mathrm{oc}}$ are the short-circuit current density $\left(\mathrm{mA} / \mathrm{cm}^{2}\right)$ and open-circuit voltage $(\mathrm{V})$ respectively, $\mathrm{J}_{\max }$ and $\mathrm{V}_{\max }$ are the short-circuit current density and the open-circuit voltage at maximum power point $\left(\mathrm{P}_{\max }\right)$ of the $\mathrm{J}-\mathrm{V}$ curve. The overall energy conversion efficiency $(\eta)$ is defined as:

$$
\eta=\left(J_{s c} \times V_{o c} \times F F\right) / P_{i n} \times 100 \%
$$

where, $\mathrm{P}_{\text {in }}$ is the power of incident light.

\subsection{Film thickness measurement}

A Dektak 150 (Veeco, USA) Stylus Surface Profiler was used to study the surface morphology and film thickness of the prepared samples. The following parameters values were set during the investigation: resolution was $0.427 \mu \mathrm{m} / \mathrm{sample}$, the time of $50 \mathrm{~s}$ was measurement time period, the force of $3 \mathrm{mg}$ was measured as stylus force with $12.5 \mu \mathrm{m}$ radius and the hills and valleys were observed as the measurement profile.

\subsection{Surface morphology and particle size measurement}

Surface morphology and particle size were examined by Field Emission Scanning Electron Microscope (FESEM) (JEOL JSM-7600F, Tokyo, Japan). At $5 \mathrm{kV}$ to $7 \mathrm{kV}$, FESEM imaging was performed.

\section{Results and discussion}

\subsection{Catalyst selection for counter elec- trode}

Fig. 1 and Table 1 present the photovoltaic performance (Voc, Jsc, FF and $\eta \%$ ) of DSSCs for counter electrodes based on various forms of carbon catalyst. All the studies in this experiment were carried out for the samples prepared in $2 \mathrm{~h}$ dye soaking time, $\mathrm{TiO}_{2}$ film thickness of $10 \mu \mathrm{m}$ and dye 
concentration of $0.135 \mathrm{~mol} / \mathrm{L}$. It has been observed (Fig. 1d), that the carbon catalyst on the counter electrode, obtained from different sources, has an effect on DSSC's efficiency [19]. Among them, nocatalyst and carbon from bamboo coal show the lowest efficiency. On the other hand, the carbon from a tip of candle flame shows the highest efficiency of $0.25 \%$ with open circuit voltage $570 \mathrm{mV}$ and short circuit current $0.90 \mathrm{~mA} / \mathrm{cm}^{2}$. This is because the electrolytic charge (ions) $\mathrm{I}^{-} / \mathrm{I}_{3}^{-}$can easily enter into the pores of the candle flame carbon atoms which influences the cell efficiency. Moreover, maybe carbon from candle flame has higher surface resistivity and better adhesion than graphite (HB/6HB pencil) and wood/bamboo coal. According to Imoto et al. [23], the performance of photovoltaic cell is greatly influenced by the roughness of carbon electrode.
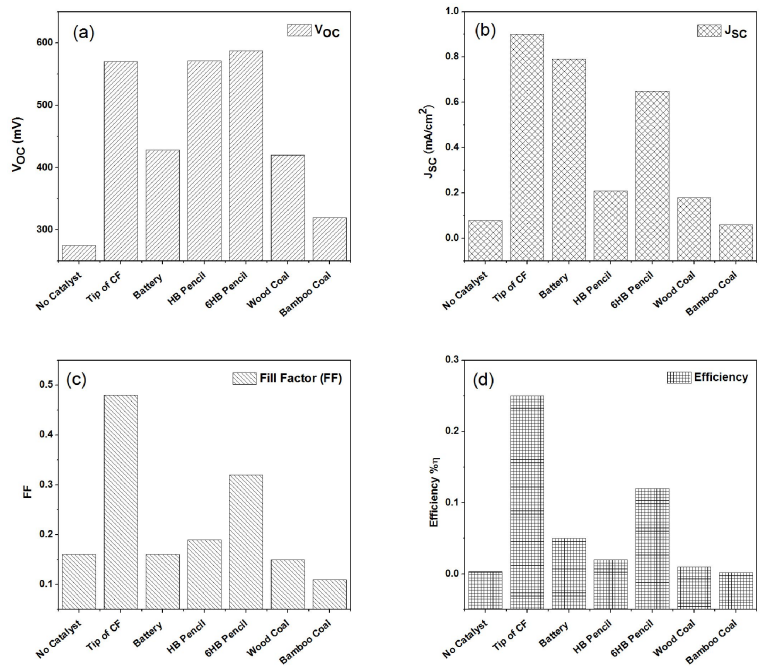

Fig. 1. (a) Open circuit voltage (Voc), (b) short circuit current (Jsc), (c) fill factor (FF) and (d) efficiency of DSSCs for various forms of carbon catalyst based counter electrodes.

\subsection{Effect of $\mathrm{TiO}_{2}$ film thickness on cell efficiency}

Fig. 2 and Table 2 present the effect of $\mathrm{TiO}_{2}$ film thickness on cell performance. Five samples of different thicknesses in the range of $5 \mu \mathrm{m}$ to $25 \mu \mathrm{m}$ were investigated. Here, the counter electrode was prepared from a tip of candle flame, and dye concentration was $0.135 \mathrm{~mol} / \mathrm{L}$ with $2 \mathrm{~h}$ dye soaking time. It has been assumed that with the increase of $\mathrm{TiO}_{2}$ film thickness, the efficiency of the cell will also increase by improving the light absorption. However, practically the cell efficiency is changing nonlinearly and non-monotonically. From Fig. 2 it is seen that the open-circuit voltage and short-circuit current swing inconsistently with the film thickness. The open-circuit voltage reaches a maximum point for $10 \mu \mathrm{m}$ film thickness whereas short-circuit current reaches the highest value for $15 \mu \mathrm{m}$. The cell efficiency reaches the peak point for $15 \mu \mathrm{m}$ film thickness. Fitra et al. [24] and Kumari et al. [25] reported the maximum efficiency obtained at lower film thickness. Baglio et al. [26] reported that they found the best efficiency at the film thickness of $10 \mu \mathrm{m}$. Rajab et al. [27] reported that for a typical DSSC, film the thickness would be approximately $10 \mu \mathrm{m}$. Higher thickness results also in the reduction of electron diffusion length increasing electron recombination. The back electron transfers increase with increasing the film thickness and therefore lowering of $\mathrm{V}_{\mathrm{OC}}$ occurs. Therefore, the cell performance would decrease [25, 27]. Short circuit current also decreases starting from a certain thickness with increasing film thickness, because series resistance increases with increasing film thickness. It is caused by the recombination of electrons with $\mathrm{I}_{3}^{-}$ions on the $\mathrm{TiO}_{2}$ surface and hence, lowering the $\mathrm{J}_{\mathrm{sc}}$ [25]. Fig. 3 shows the inverted microscope images of the samples of different thicknesses, where a lot of cracks are observed. From these images, it is clear that with increasing thickness, the crack size and width increase which may reduce the charge transfer from $\mathrm{TiO}_{2}$ surface to ITO coated surface.

\subsection{Effect of dye concentration on cell ef- ficiency}

In previous section 4.2, we found that $\mathrm{TiO}_{2}$ film of $15 \mu \mathrm{m}$ thickness showed the maximum efficiency. In this section, the effect of dye concentration on cell efficiency for the samples of $15 \mu \mathrm{m}$ thickness was studied. The $5 \mathrm{~g}$ of dry turmeric was mixed with $50 \mathrm{~mL}, 100 \mathrm{~mL}$ and $200 \mathrm{~mL}$ ethanol solvent and the molar concentration of the dye was 
Table 1. Photovoltaic response of DSSCs cell for various forms of carbon catalyst based counter electrodes.

\begin{tabular}{lcccc}
\hline Catalyst name & $\mathrm{V}_{\mathrm{oc}}[\mathrm{mV}]$ & $\mathrm{J}_{\mathrm{sc}}\left[\mathrm{mA} / \mathrm{cm}^{2}\right]$ & Fill factor & Efficiency [\%] \\
\hline \hline No Catalyst & 275 & 0.08 & 0.16 & 0.003 \\
Tip of candle flame & 570 & 0.90 & 0.48 & 0.25 \\
Battery & 428 & 0.79 & 0.16 & 0.05 \\
HB pencil & 571 & 0.21 & 0.19 & 0.02 \\
6HB pencil & 587 & 0.65 & 0.32 & 0.12 \\
Wood coal & 420 & 0.18 & 0.15 & 0.01 \\
Bamboo coal & 320 & 0.06 & 0.11 & 0.002 \\
\hline
\end{tabular}

Table 2. Photovoltaic response of DSSCs with photoanodes based on $\mathrm{TiO}_{2}$ film with various thicknesses.

\begin{tabular}{ccccc}
\hline $\begin{array}{c}\mathrm{TiO}_{2} \text { film thickness } \\
{[\mu \mathrm{m}]}\end{array}$ & $\mathrm{V}_{\mathrm{oc}}[\mathrm{mV}]$ & $\mathrm{J}_{\mathrm{sc}}\left[\mathrm{mA} / \mathrm{cm}^{2}\right]$ & Fill factor & Efficiency [\%] \\
\hline \hline 5 & 240 & 0.17 & 1.55 & 0.06 \\
10 & 520 & 0.83 & 0.35 & 0.15 \\
15 & 446 & 0.95 & 0.63 & 0.27 \\
20 & 458 & 0.67 & 0.45 & 0.14 \\
25 & 540 & 0.49 & 0.46 & 0.12 \\
\hline
\end{tabular}
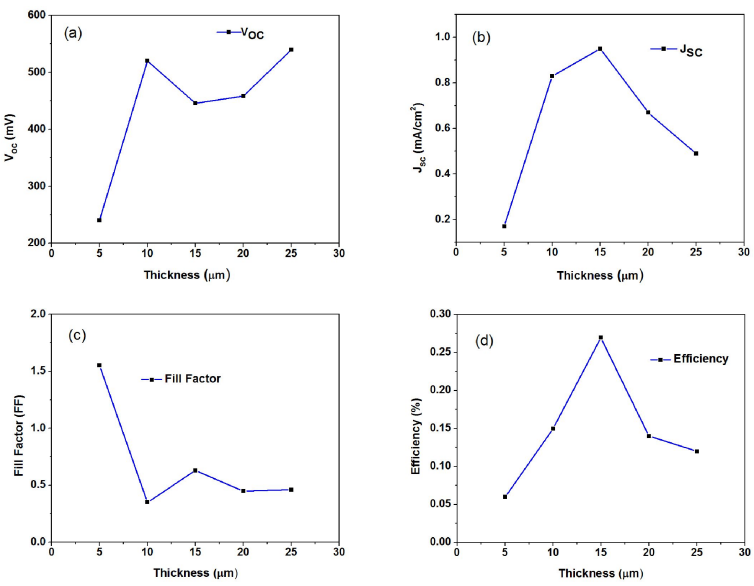

Fig. 2. (a) Open circuit voltage $\left(\mathrm{V}_{\mathrm{oc}}\right)$, (b) short circuit current $\left(\mathrm{J}_{\mathrm{sc}}\right)$, (c) fill factor (FF) and (d) efficiency of DSSCs for photoanodes with different $\mathrm{TiO}_{2}$ film thicknesses.

calculated and tabulated in Table 3 according to the following formula:

Molar concentration $=($ sample weight $\times 1000)$ /(sample molecular mass $\times$ solvent volume $)[\mathrm{mol} / \mathrm{L}]$

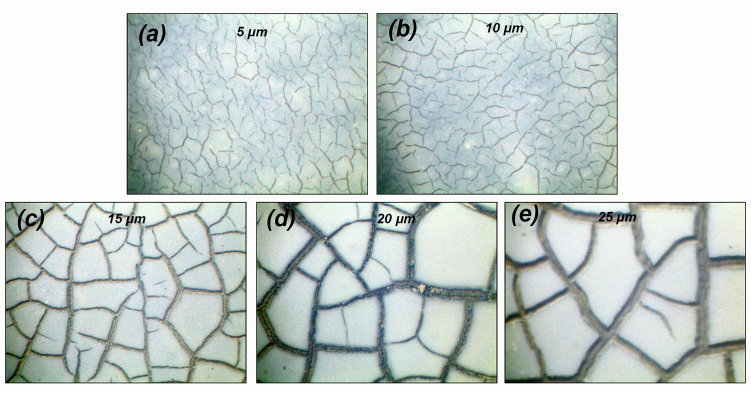

Fig. 3. $\mathrm{TiO}_{2}$ films inverted microscopic images $(\times 10$ magnifications) for samples with thicknesses of (a) $5 \mu \mathrm{m}$, (b) $10 \mu \mathrm{m}$, (c) $15 \mu \mathrm{m}$, (d) $20 \mu \mathrm{m}$ and (e) $25 \mu \mathrm{m}$.

where sample weight is in $\mathrm{g}$, solvent volume is in $\mathrm{mL}$ and molar mass of turmeric is $368.39 \mathrm{~g} / \mathrm{mol}$.

It is observed from Fig. 4 and Table 3 for $2 \mathrm{~h}$ soaking time samples, that the cell efficiency has increased when the dye concentration was increased. Though it is not firmly proved that the efficiency increases with increasing dye concentration but it has been found in this research that the efficiency increased from $0.31 \%$ to $0.45 \%$ while the dye concentration was changed. Chou et al. [28]

(3) showed that the cell efficiency was increased with 
the increased dipping time for low dye concentration, and also indicated that higher concentration and lower dipping time lead to better efficiency. Table 3 shows the photovoltaic parameters of samples obtained after 2 hour soaking time in dyes with three different concentrations and Fig. 5 shows the $\mathrm{J}_{\mathrm{sc}}-\mathrm{V}$ characteristics curve for the most efficient cell.

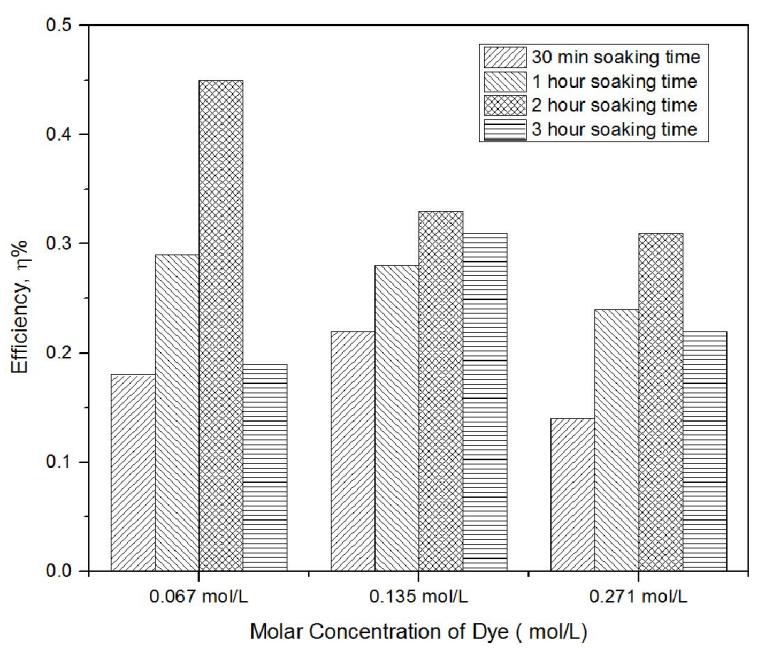

Fig. 4. Effect of dye concentration on cell efficiency.

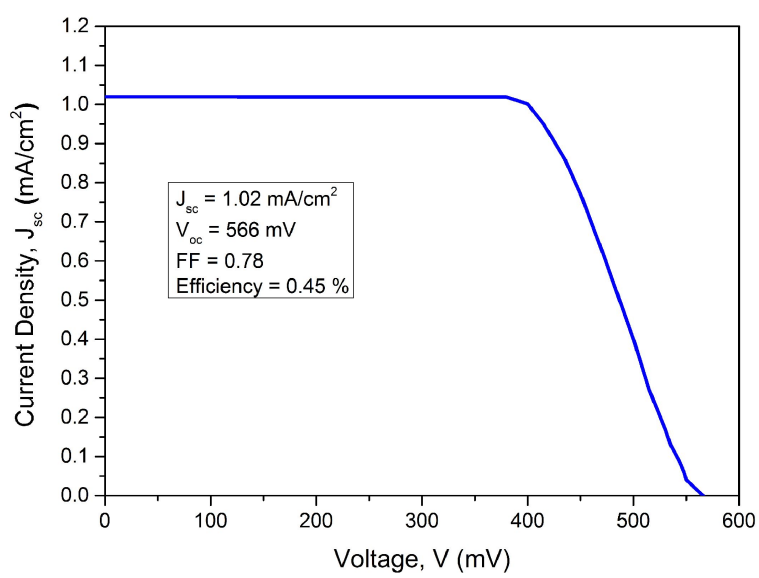

Fig. 5. $\mathrm{J}_{\mathrm{sc}}-\mathrm{V}$ characteristics for the optimized DSSC.

\subsection{Surface morphology analysis of $\mathrm{TiO}_{2}$ film by surface profiler for optimized cell}

Fig. 6 shows the surface morphology, examined by the Dektak-150 surface profiler for the optimized cell photoanode before dipping into the dye. For $\mathrm{TiO}_{2}$ film coating thickness measured by the Dektak-150, a total $75 \mu \mathrm{m}$ active $\mathrm{TiO}_{2}$ coating length of the sample was measured. Letters $\mathrm{R}$ and $\mathrm{M}$ i.e. red and green shaded areas inside Fig. 6 represent the reference and measured area of the film to estimate the film coating thickness. On ITO glass substrate, $15 \mu \mathrm{m}$ thickness of $\mathrm{TiO}_{2}$ coating was found. As it is seen in Fig. 6, the surface is almost even with the negligible fluctuation of about $50 \AA$ to $100 \AA$. These fluctuations might have occurred due to the presence of dust particles [29].

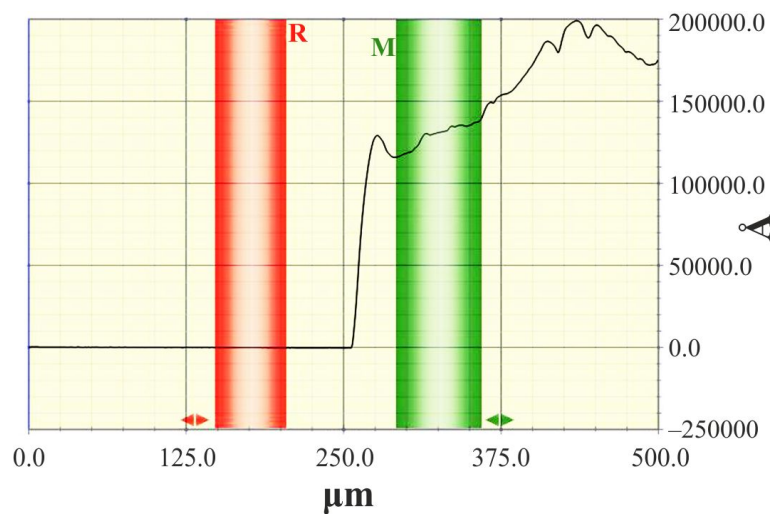

Fig. 6. Thickness of $\mathrm{TiO}_{2}$ film for optimized DSSC on ITO glass substrate measured by surface profiler.

\subsection{SEM analysis of $\mathrm{TiO}_{2}$ film for opti- mized cell}

Scanning electron microscopy (SEM) was used to observe the morphological features of the $\mathrm{TiO}_{2}$ nanoporous thin film surface after heat treatment of DSSC photoanode (Fig. 7a) and after adsorbing of dye on the surface of $\mathrm{TiO}_{2}$ nanoporous thin film (Fig. 7b). It is revealed that the spherical $\mathrm{TiO}_{2}$ nanoparticles with an average size around $10 \mathrm{~nm}$ to $20 \mathrm{~nm}$, are homogenously distributed and clustered together. It is observed from Fig. 7a that there are lots of pores in $\mathrm{TiO}_{2}$ matrix which is very important so as the dye could enter into the nanosized matrix. It can be seen that on the surface and in the spaces between the layers of the coating no fractures exist. It indicates a good connection of interparticles and interlayers. $\mathrm{TiO}_{2}$ coated surface of the photoanode is rough, but the roughness can be reduced by using spin-coater. A significant 
Table 3. Photovoltaic response of DSSCs obtained after 2 hour soaking time in dye with different molar concentrations.

\begin{tabular}{ccccccc}
\hline $\begin{array}{c}\text { Added amount of } \\
\text { turmeric dye }[\mathrm{g}]\end{array}$ & $\begin{array}{c}\text { Volume of } \\
\text { ethanol }[\mathrm{mL}]\end{array}$ & $\begin{array}{c}\text { Molar concentration of dye } \\
{[\mathrm{mol} / \mathrm{L}]}\end{array}$ & $\begin{array}{c}\mathrm{V}_{\mathrm{oc}} \\
{[\mathrm{mV}]}\end{array}$ & $\begin{array}{c}\mathrm{J}_{\mathrm{sc}} \\
{\left[\mathrm{mA} / \mathrm{cm}^{2}\right]}\end{array}$ & Fill factor & $\begin{array}{c}\text { Efficiency } \\
{[\%]}\end{array}$ \\
\hline \hline 5 & 200 & 0.067 & 500 & 0.63 & 0.99 & 0.31 \\
5 & 100 & 0.135 & 494 & 0.08 & 8.48 & 0.33 \\
5 & 50 & 0.271 & 566 & 1.02 & 0.78 & 0.45 \\
\hline
\end{tabular}
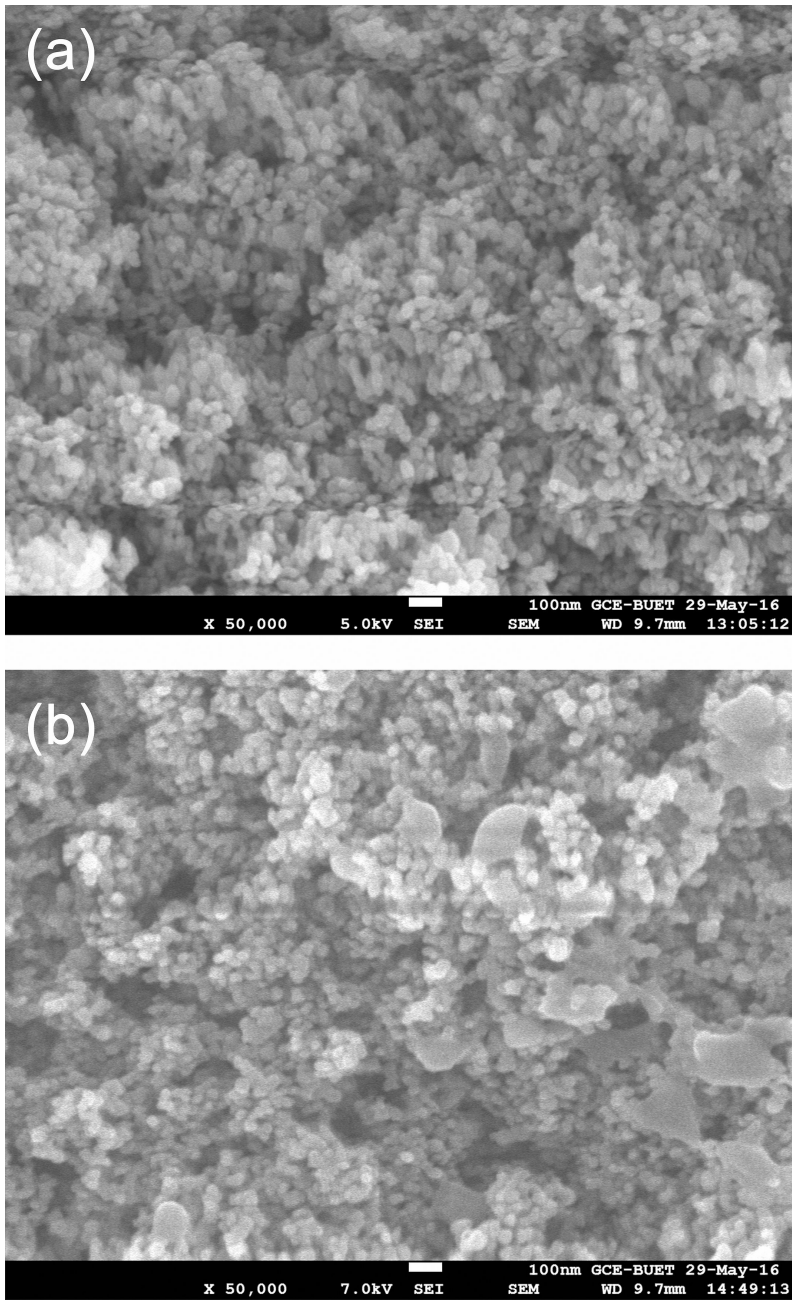

Fig. 7. SEM images of nanostructured $\mathrm{TiO}_{2}$ film of optimized DSSC on ITO glass substrate annealed at $450{ }^{\circ} \mathrm{C}$ for 1 hour (a) before (b) after sensitization in dye in 50,000 magnification.

variation was observed between the adsorbed dye sample and no dye sample. As shown in Fig. 7b, the highest number of the nanopores are filled by the molecules of the used dye [30].

\section{Conclusions}

In the present study, natural dye based dye sensitized solar cells were successfully fabricated and optimized. The optimization of the solar cell was done in terms of counter electrode catalyst material, photoanode thickness, and dye concentration. Extracted photoanode were characterized by inverted microscope, surface profiler and scanning electron microscope. Photovoltaic characteristics of the fabricated cells were studied in terms of cell efficiency. The best optimized cell photoanode thickness was $15 \mu \mathrm{m}$, soaking time in ethanol extracted dye was 2 hours and the counter electrode catalyst material was a candle flame carbon. In optimized condition, the photovoltaic parameters $\mathrm{V}_{\mathrm{oc}}$, $\mathrm{I}_{\mathrm{sc}}, \mathrm{FF}$, power density and efficiency were $566 \mathrm{mV}$, $1.02 \mathrm{~mA} / \mathrm{cm}^{2}, 0.78$ and $0.45 \%$, respectively. The morphology of the optimized cell showed good nanoporous $\mathrm{TiO}_{2}$ film with a smooth flat surface.

\section{Acknowledgements}

The authors would like to acknowledge the help of Dept. of GCE, BUET, Bangladesh, by providing the laboratory facilities to perform SEM analysis, and the financial grant provided by IDCOL and supported by MOST, Bangladesh. Photoanode's film thickness measurement was carried out at the Center of Excellence for VLSI Technology, Institute of Electronics, Atomic Energy Research Establishment, Dhaka, Bangladesh.

\section{References}

[1] Wüstenhagen R., Wolsink M., Bürer M.J., Energ. Policy, 35 (2007), 2683.

[2] Hagfeldt A., Boschloo G., Sun L., Kloo L., Pettersson H., Chem. Rev., 110 (2010), 6595.

[3] Lim A., Kumara N.T.R.N., TAN A.L., Mirza A.H., Chandrakanthi R.L.N., Petra M.I., Ming L.C., Senadeera G.K.R., Ekanayake P., Spectrochim. Acta A, 138 (2015), 596.

[4] Ludin N.A., Mahmoud A.M.A.-A., Mohamad A.B., KADHUM A.A.H., Sopian K., KARIM N.S.A., Renew. Sust. Energ. Rev., 31 (2014), 386. 
[5] O’RegAn B., GRÄTzel M., Nature, 353 (1991), 737.

[6] Grätzel M., J. Photoch. Photobio. C, 4 (2003), 145.

[7] Treat N.A., Knorr F.J., Mchale J.L., J. Phys. Chem. C, 120 (2016), 9122.

[8] JARKKo E., Eur. J. Young Sci. Eng., 1 (2012), 1.

[9] Mathew S., Yella A., GaO P., HumphryBaKer R., Curchod B.F.E., Ashari-Astani N., TAVERnelli I., Rothlisberger U., NAZEERUdDiN M.K., GRÄTZEL M., Nat. Chem., 6 (2014), 242.

[10] Kim H.-J., Bin Y.-T., Karthick S.N., Hemalatha K.V., Raj C.J., Venkatesan S., Park S., ViJAYAKUMAR G., Int. J. Electrochem. Sc., 8 (2013), 6734.

[11] Shalini S., Prabhu R.B., Prasanna S., Mallick T.K., Senthilarasu S., Renew. Sustain. Energy Rev., 51 (2015), 1306.

[12] PARK K.-H., Kim T.-Y., PARK J.-Y., Jin E.-M., Yim S.-H., ChOI D.-Y., LeE J.-W., Dye. Pigment., 96 (2013), 595.

[13] AL-Alwani M.A.M., Mohamad A.B., Kadhum A.A.H., LUdIN N.A., Spectrochim. Acta A., 138 (2015), 130.

[14] Narayan M.R., Renew. Sust. Energ. Rev., 16 (2011), 208.

[15] Shanmugam V., Manoharan S., Sharafali A., Anandan S., Murugan R., Spectrochim. Acta A., 135 (2015), 947.

[16] Kim H.J., Kim D.J., Karthick S.N., Hemalatha K.V., RAJ C.J., OK S., ChOE Y., Int. J. Electrochem. Sc., 8 (2013), 8320.

[17] Kakiage K., Aoyama Y., Yano T., Otsuka T., KYomen T., Unno M., Hanaya M., Chem. Commun., 50 (2014), 6379.

[18] Teoli F., Lucioli S., Nota P., Frattarelli A., Matteocci F., Carlo A.D., Caboni E., Forni C., J. Photoch. Photobio. A, 316 (2016), 24.
[19] Hossain M.K., Pervez M.F., Mia M.N.H., MorTUZA A.A., RAHAMAN M.S., KARIM M.R., ISLAM J.M.M., Ahmed F., Khan M.A., Results Phys., 7 (2017), 1516.

[20] Uddin J., Islam J.M.M., Khan S.M.M., Hoque E., Khan M.A., Int. Lett. Chem. Phys. Astron., 39 (2014), 78.

[21] Hossain M.K., Rahaman M.S., Mortuza A.A., Haque M.A.S., Ghosh H.K., Hoq M., Ahmed F., KHAN M.A., National Conference on Physics-2017, Bangladesh Physical Society, Dhaka, 2017.

[22] Fatai A., Adenike B., Surukite O., Ibrahim A., J. Nat. Sci. Res., 3 (2013), 2225.

[23] Imoto K., Takahashi K., Yamaguchi T., Komura T., Nakamura J., Murata K., Sol. Energ. Mat. Sol. C., 79 (2003), 459.

[24] Fitra M., Daut I., Irwanto M., Gomesh N., IRWAN Y.M., Energ. Procedia., 36 (2013), 278.

[25] Kumari J.M.K.W., SANJeEVAdharshini N., DisSANAYAKE M.A.K.L., SENADEERA G.K.R., Thotawatthage C.A., Ceylon J. Sci., 45 (2016), 33.

[26] Baglio V., Girolamo M., Antonucci V., Aricò A.S., Int. J. Electrochem. Sc., 6 (2011), 3375.

[27] RAJAB F.M., J. Nanomater., 2016 (2016), 1.

[28] Chou T.P., Zhang Q., CaO G., J. Phys. Chem. C., 111 (2007), 18804.

[29] Alam M.M., Mia M.N.H., Hasan R., ShahinuZZAMAN M., ISLAM M.K., UDDIN K.M.N., Mater. Sci. Appl., 6 (2015), 753.

[30] Miah M.H., Rahaman M.D., Syed I.M., Bangladesh J. Phys., 18 (2015), 1.

Received 2017-03-23 Accepted 2017-09-25 